\title{
The Latest Approaches Regarding Structural Funds Absorption - Romania vs. Central and Eastern European New Member States
}

\author{
ZAI Paul Vasile \\ Babeş Bolyai University, Cluj-Napoca, Romania \\ Correspondence should be addressed to: ZAI Paul Vasile; zai@fspac.ro \\ Received date: 4 September 2014; Accepted date: 13 December 2014; Published date: 14 September 2015 \\ Academic Editor: Rozalia Kicsi \\ Copyright (C) 2015. ZAI Paul Vasile . Distributed under Creative Commons CC-BY 4.0

\begin{abstract}
This paper is trying to present in a modern manner the absorption of structural funds in Romania vs Central Eastern European countries. The methodology that we used combines quantitative methods with qualitative research. It was made a detailed presentation on the amounts allocated, contracted and paid in Romania and Central-Eastern European states. The EU allocated amount per capita is 2504 Eur in the Czech Republic (population 10,5 mil. Inhabitants) and at the opposite site is Romania with 1102 Eur(population 21,4 mil. inhabitants).We also addressed issues related to the perception of beneficiaries on the absorption of structural funds, problems, recommendations, and expectations. While most new member states focus on OP Transport and OP Environment, in Romania the situation has remained unchanged each year, that is Regional Operational Program has top priority ahead of any operational program. The CEE allocated amount is 209,1 bil. Eur, the contracted amounts are $85 \%$ and the payments are $44 \%$. The highest contacted amounts are in Bulgaria and Latvia and the highest payments are in Estonia and Lithuania (59\%).
\end{abstract}

Keywords: allocation; funds absorption; structural funds, contracted amounts;

\section{Introduction}

The 2007-2013 programming period provides the possibility for the 10 new EU member states located in Central and Eastern Europe to absorb 209,138 billion Euros, a sum which was allocated by the European Commission with an aim to reduce the gaps between the development regions of the said states and to sustain a uniform level of economic development both among themselves and the other E.U. Member States. The sums allocated from the 3 funds (ERDF, ESF and CF) vary between the states, according to the population and GDP per capita of each (KPMG, 2011).

The Methodology that we used to study these elements is quite large, represented by method

Cite this Article as: ZAI Paul Vasile (2015)," The Latest Approaches Regarding Structural Funds Absorption Romania vs. Central and Eastern European New Member States ", Journal of Eastern Europe Research in Business and Economics, Vol. 2015 (2015), Article ID 178521, DOI: 10.5171/2015.178521 
paradigm that combines quantitative methods with qualitative research. The importance of qualitative methods is the fact that they focus on issues and detailing aspects of interest in the evaluation process in order to achieve a high level of understanding of the issues studied.

The quantitative approach is composed of two research methods: analysis of secondary data and survey. Thus, we conducted analysis of information / data reflected in documents prepared by competent authorities and institutions and specialized in issuing such statistics: Ministry of European Funds, the Authority for Coordination of Structural
Instruments, Ministry of Finance, Eurostat, National Statistical Institute. We used also official statements and notes published on the official website of the Ministry of European Funds and the Romanian Government.

A survey, with structured questionnaire as a research tool, was applied exhaustively to beneficiaries or potential beneficiaries of projects financed from structural funds, from: Inter Municipal Cooperation Associations active in Romania, the Association of Municipalities of Romania, Association of Cities of Romania, the Association of Municipalities in Romania, and the National Union of County Councils of Romania.

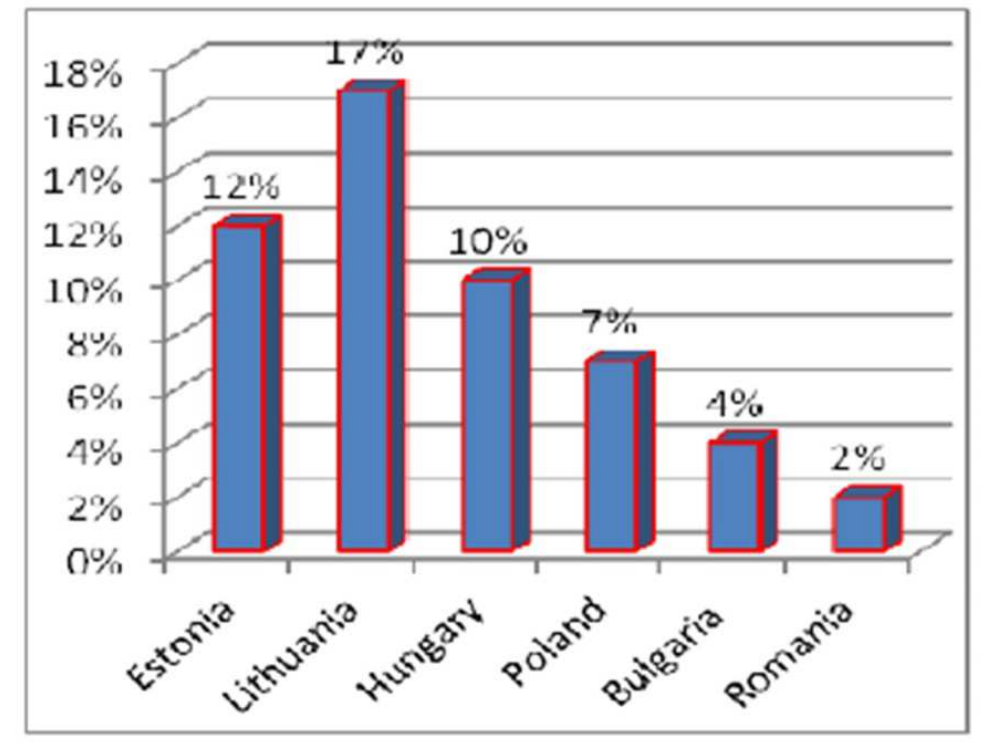

Figure: 1 SF absorption rate 2007-2009 
Table 1: The financial allocation in the 10 new Central and Eastern European EU member states, according to population and GDP

\begin{tabular}{|c|c|c|c|c|c|c|c|c|c|c|c|}
\hline & 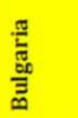 & ક气 & $\frac{\pi}{\tilde{\Xi}}$ & 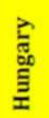 & 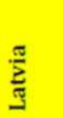 & 紕 & $\begin{array}{l}\bar{\Xi} \\
\frac{\pi}{0} \\
2\end{array}$ & 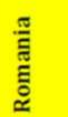 & $\begin{array}{l}\frac{\pi}{\frac{\pi}{\pi}} \\
\frac{0}{4}\end{array}$ & $\frac{\text { के }}{\frac{0}{\pi}}$ & छ్ \\
\hline $\begin{array}{l}\text { Population } \\
\text { (mil.) }\end{array}$ & 7,4 & 10,5 & 1,3 & $\begin{array}{c}10, \\
0\end{array}$ & 2 & 3 & 38,5 & 21,4 & 5,4 & 2,1 & 101,5 \\
\hline $\begin{array}{l}\text { Annual GDP } \\
\text { (bil. Euros) }\end{array}$ & 39,7 & $\begin{array}{c}152 \\
8\end{array}$ & 17 & $\begin{array}{c}97, \\
8\end{array}$ & 22,3 & 32,8 & $\begin{array}{c}381 \\
4\end{array}$ & $\begin{array}{c}131 \\
7\end{array}$ & 71,5 & 35,5 & 982,5 \\
\hline $\begin{array}{l}\text { GDP per } \\
\text { capita }\end{array}$ & 5,414 & $\begin{array}{c}14,5 \\
48\end{array}$ & $\begin{array}{c}12,6 \\
88\end{array}$ & $\begin{array}{l}9,8 \\
17\end{array}$ & $\begin{array}{c}10,9 \\
01\end{array}$ & $\begin{array}{c}10,8 \\
99\end{array}$ & $\begin{array}{c}9,89 \\
6\end{array}$ & $\begin{array}{c}6,16 \\
9\end{array}$ & 13,223 & 17,254 & 9,675 \\
\hline \multirow{2}{*}{$\begin{array}{l}\begin{array}{l}\text { Allocated } \\
\text { budget }\end{array} \\
\text { 2007-2013 } \\
\text { (mil. Euro) }\end{array}$} & 6,67 & $\begin{array}{c}26,3 \\
1\end{array}$ & 3,40 & $\begin{array}{l}24, \\
92\end{array}$ & 4,55 & 6,78 & $\begin{array}{c}67,1 \\
9\end{array}$ & $\begin{array}{l}23, \\
53\end{array}$ & 11,50 & 4,10 & 178,9 \\
\hline & $4 \%$ & $15 \%$ & $2 \%$ & $\begin{array}{l}14 \\
\%\end{array}$ & $2 \%$ & $4 \%$ & $40 \%$ & $11 \%$ & $6 \%$ & $2 \%$ & $100 \%$ \\
\hline $\begin{array}{l}\text { EU funds per } \\
\text { capita (Euros) }\end{array}$ & 911 & $\begin{array}{c}2,50 \\
4\end{array}$ & $\begin{array}{c}2,54 \\
1\end{array}$ & $\begin{array}{l}2,5 \\
03\end{array}$ & $\begin{array}{c}2,22 \\
7\end{array}$ & $\begin{array}{c}2,25 \\
3\end{array}$ & $\begin{array}{c}1,74 \\
3\end{array}$ & $\begin{array}{c}1,10 \\
2\end{array}$ & 2,128 & 1,995 & - \\
\hline \multicolumn{12}{|c|}{ Source: KPMG study, 2013:7 } \\
\hline
\end{tabular}

Source: Personal processing after KPMG, 2010

\section{Study case}

Owing to its being the country with the largest number of population, Poland was allocated 67,19 million Euros, which represent almost half of the total budget assigned to this area. The second position in financial allocation is held by the Czech Republic, which has $15 \%$ of the total budget allocated to the C - EE states, representing 26,31 million Euros, although the largest GDPs per capita are in Slovenia and the Czech Republic.

Bârgăoanu A. (2004) and Ibraim, M. (2007) mentioned that post-accession slow absorption rate is not an issue that concerns solely Romania, many of the member states have dealt with the same problem. However, Romania became a member state six years ago, and we are rapidly approaching the end of the programming period, without registering progress in the absorption and use of the allocated funds, instead the Romanian state risks reimbursing part of the received sum, following the irregularities identified by the European Commission in the management process of the operational programmes.

Three years after Romania became an EU member state, the percentage of structural funds' absorption was at half the rate of its "fellow" Bulgaria, our country attracting only $2 \%$ of the total funds allocated by the European Commission for the period 2007 2013. At the end of 2012, the Structural Funds contracting rate for the 10 new member states was at $85 \%$ of the total allocated sum for the 2007-2013 period. Leading the ranks are Bulgaria, the Czech Republic and the Baltic States, Estonia, Latvia and Lithuania, while the countries with the largest budget to attract are Slovenia, Slovakia, Hungary and Romania. 


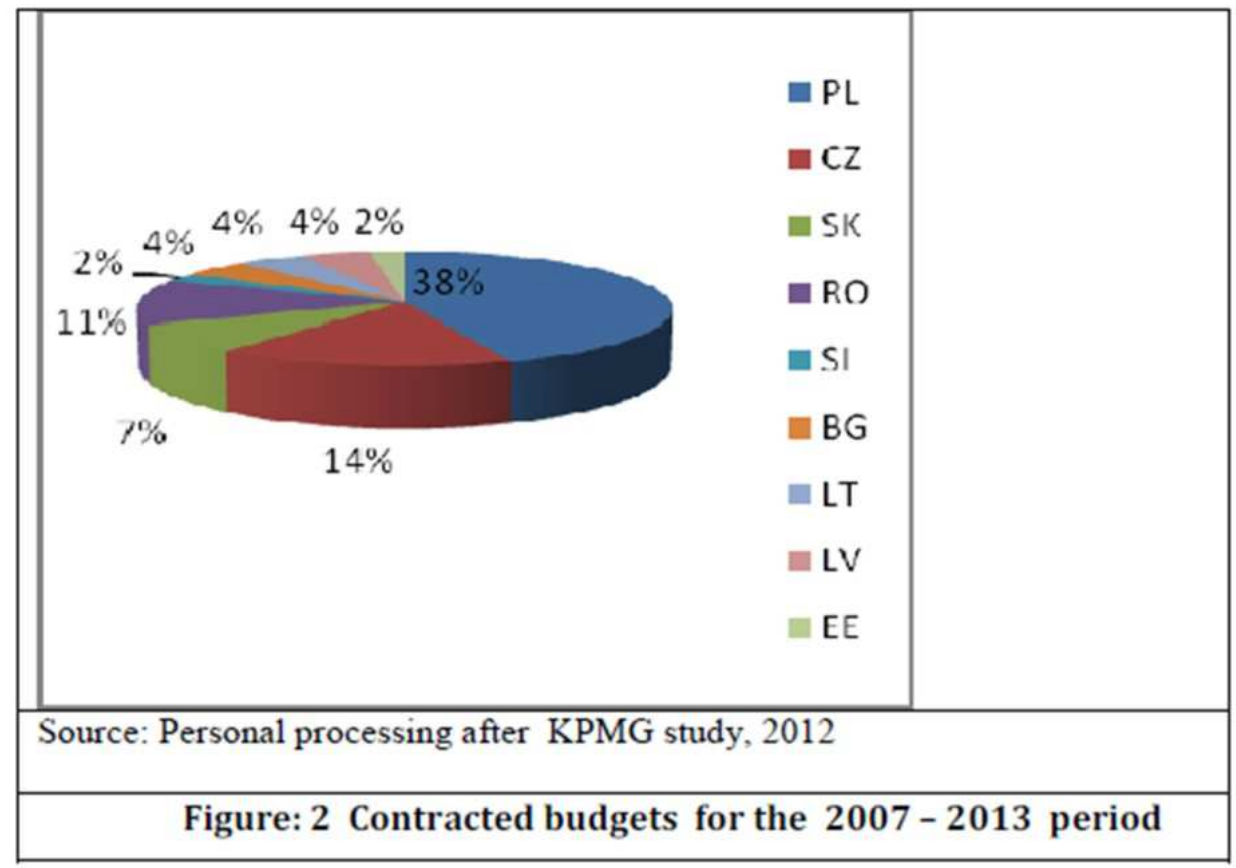

According to the major intervention area, the Operational Programmes that have the largest contracting rates are as follows:

In Romania, the situation is substantially different: the largest rate for our country can be found in the Human Resource Development and Administrative Capacity areas. Although there is a high percentage of sums from structural funds allocated by the European Commission for Romania, we are witnessing incompetence by Romania to manage this Programme 


\begin{tabular}{|c|c|c|c|c|c|c|c|c|c|}
\hline \multirow[t]{3}{*}{ C - EIE states } & & \multicolumn{8}{|c|}{ Contracting rate and payments in $\mathrm{C}-\mathrm{EE}$ states Table no. 2} \\
\hline & \multicolumn{5}{|c|}{ Contracting rate $(\%)$} & \multicolumn{4}{|c|}{ Payments made (\%) } \\
\hline & 2008 & 2009 & 2010 & 2011 & 2012 & 2009 & 2010 & 2011 & 2012 \\
\hline Bulgaria & 11 & 24 & 37 & 79 & 100 & 3 & 10 & 19 & 34 \\
\hline Czech Republi & 16 & 28 & 56 & 72 & 90 & 9 & 26 & 39 & 57 \\
\hline Estonia & 11 & 48 & 60 & 94 & 91 & 11 & 21 & 44 & 59 \\
\hline Hungary & 20 & 38 & 51 & 64 & 78 & 9 & 16 & 28 & 40 \\
\hline Latvia & 0 & 45 & 67 & 87 & 94 & 15 & 29 & 44 & 56 \\
\hline Lithuania & 18 & 47 & 76 & 78 & 91 & 14 & 30 & 43 & 59 \\
\hline Poland & 3 & 25 & 53 & 63 & 83 & 6 & 16 & 28 & 49 \\
\hline Romania & 5 & 16 & 45 & 63 & 88 & 3 & 5 & 7 & 11,47 \\
\hline Slovakia & 12 & 24 & 56 & 64 & 73 & 5 & 17 & 28 & 41 \\
\hline Slovenia & 23 & 34 & 48 & 59 & 72 & 15 & 27 & 38 & 50 \\
\hline $\begin{array}{l}\text { C-EE averag } \\
\text { (2007-2012) }\end{array}$ & 9 & 28 & 53 & 67 & 85 & 7 & 17 & 28 & 44 \\
\hline Source: own in & iterpr & $n$ of $E$ & stat an & MG stu & 5 regar & & & & \\
\hline
\end{tabular}

The table above outlines the fact that in the 6 years passed of the 2007 - 2013 programming period, the overall absorption is relatively good, considering that the $10 \mathrm{C}$ - EE states have managed together to reach a contracting rate of $85 \%$ and a payments rate made of $44 \%$. Regarding the contracting rate, we see that the largest evolution was registered in the 20092010 period, with an increase from $9 \%$ to $28 \%$ at the end of 2009 and an increase of $28 \%$ to $53 \%$ in 2010 .
At the state level, the largest contracting rate is registered in Bulgaria, with $100 \%$, followed by the Baltic States: Latvia, with 94\%, Estonia and Lithuania with a contracting rate of $91 \%$ each.

Slovakia has the weakest performance regarding project contracting, with 73\%, followed by Slovenia with $72 \%$. While the evolution of Slovenia was constant, increasing by $11-14 \%$ annually, a significant increase by Romania in this respect was registered starting with 2010, when its contracting rate tripled (from $16 \%$ to $45 \%$ ), thus reaching a rate of $63 \%$ by the end of 2011 . 


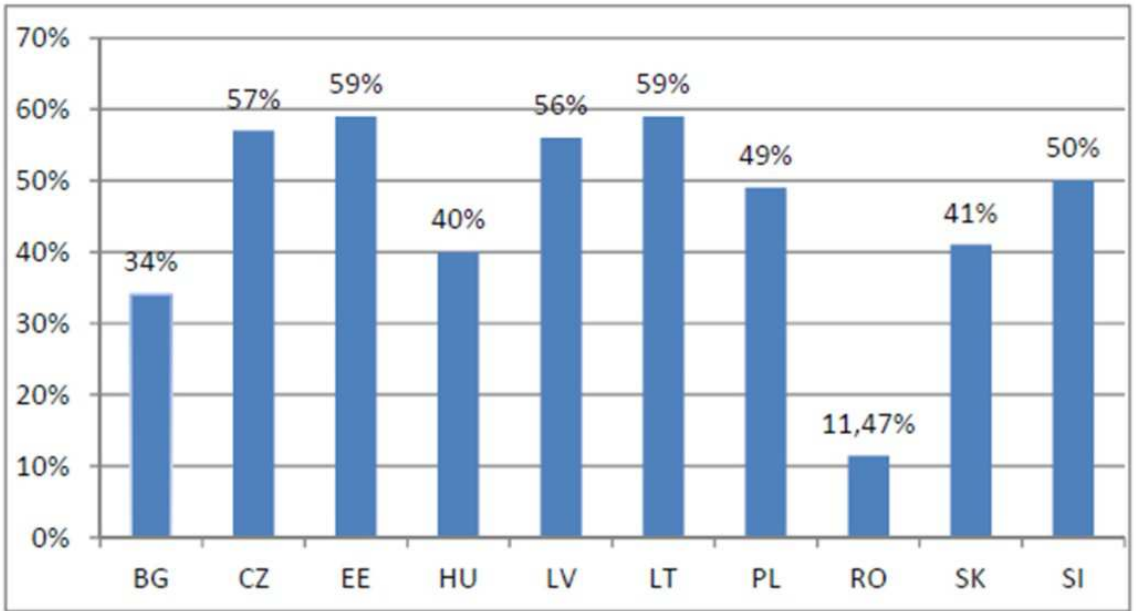

Source: own processing after KPMG, 2013

\section{Figure: 3 Structural and Cohesion Funds absorption rate in C - EE states (31.12.2012)}

In the field of amounts paid, the situation does not vary very much, the first three rankings are held by the Baltic States, the difference being that each year the top ranking is held by a different state. Thus, if at the end of 2009, the top ranking was held by Latvia, in 2010 Lithuania was the one that occupied this spot, while at the end of 2011 it was "shared" by Estonia and Latvia, Lithuania being second. At the end of 2012, Estonia and Lithuania held the first place in the ranking of the states with the highest rate of payments made (59\%), followed by the Czech Republic with $57 \%$.

Regarding the proper absorption of structural funds, the situation is detailed in the graphic below:

At the end of 2012, the absorption rate for structural funds in Romania was of less than 6 times higher than 2009 (11,47\%), ranking last at this chapter as well, being surpassed also by Bulgaria. Lithuania and Estonia are the countries with the highest absorption rates $59 \%$, succeeding to attract 4 billion Euros (out of 6,8 billion) - Lithuania and 2 billion (out of 3,4 billion) - Estonia. The immediate ranking is held by the Czech Republic, with a $57 \%$ rate $(16,2$ billion euros). At the bottom of the rankings we have Bulgaria with an absorption rate of $34 \%$ (2,3 billion Euros) and trailing Romania with an absorption rate of less than $12 \%$, succeeding to attract only 2,8 billion Euros out of a total of 19,2 billion allocated 6 years ago. At the end of 2013, Romania managed to absorb 26,49\%, and in August 2014 it has surpassed 33\%.

In a comparison with the neighbouring country, we see that the difference between the absorption rates of the two is extremely high, but if we look at the evolution of Lithuania, which had an absorption rate of $17 \%$ in 2009 , we can conclude that the EU funds attraction process in our country is extremely slow, considering that in the same period of time since their admission to the EU, Lithuania manages to absorb $17 \%$, Estonia $12 \%$, while Romania manages to develop projects amounting to a value of only $7,45 \%$ of the total sum allocated for the 2007-2013 period.

Also, we cannot ignore the performance of Bulgaria which, although like Romania which is in its first programming period, managed to reach a $34 \%$ rate regarding structural funds absorption, surpassing Romania with 22,53\%. 
The common issues which affect both the organizations that have benefited from financing through structural funds, as well as those who did not, are: excessive bureaucracy, precarious human resources training - both their own and that of public institutions with which they interact - a lack of financial resources, institutional issues, the decline of the collaboration with partners, as well as public procurement. (See GEO no. 66/2011, GE0 no. 52/2013 GD no. 218/2012)

Curteanu D. (2005) and Florescu M. (2008) pointed that the specific issues that beneficiary organizations have to tackle are: the evaluation phase of the financing and reimbursement requests, the increased fluctuation of personnel during the implementation of a project, political and legal instability, and the lack of resources for keeping the personnel involved in the implementation of projects.

A positive outcome is that both the organizations that have gathered experience in accessing structural funds from Romania, as well as those who have not managed to implement such projects intend to access structural funds in the future programming period, 2014-2020. This perception is based on the beneficiaries' view on the importance of structural funds in the economic development of the country and the degree of accessibility of this financing source.

Table 3: Absorption of structural funds on each Operational Program in Romania, 31 December 2013

\begin{tabular}{|c|c|c|c|c|c|c|c|c|c|c|}
\hline \multirow[t]{2}{*}{$\begin{array}{c}\text { Table no.3 } \\
\text { OP2 }\end{array}$} & \multicolumn{2}{|c|}{$\begin{array}{l}\text { Allocations EU } \\
\text { 2007-2013 }\end{array}$} & \multicolumn{2}{|c|}{ Contracting Rate } & \multicolumn{2}{|c|}{$\begin{array}{c}\text { Internal } \\
\text { payments to } \\
\text { beneficiaries }\end{array}$} & \multicolumn{2}{|c|}{$\begin{array}{l}\text { Declarations of } \\
\text { expenditure } \\
\text { submitted to the } \\
\text { EC }\end{array}$} & \multicolumn{2}{|c|}{$\begin{array}{l}\text { The rate of } \\
\text { absorption }\end{array}$} \\
\hline & $\begin{array}{l}\text { mil. } \\
\text { euro }\end{array}$ & mil. lei & mil. lei & $\%$ & $\begin{array}{l}\text { mil. } \\
\text { lei }\end{array}$ & $\%$ & $\begin{array}{l}\text { mil. } \\
\text { euro }\end{array}$ & $\%$ & $\begin{array}{l}\text { mil. } \\
\text { euro }\end{array}$ & $\%$ \\
\hline POS & & & & & & & & & & \\
\hline $\mathrm{Tra}^{3}$ & 4426 & 20592 & 15720 & 76,34 & 4757 & 24,23 & 1382 & 31,23 & 876 & 19,80 \\
\hline POS Env 4 & 4412 & 20351 & 20365 & 100 & 6250 & 31,93 & 1176 & 26,65 & 1052 & 23,84 \\
\hline ROP5 & 3966 & 16804 & 18373 & 109,33 & 8083 & 45,94 & 1779 & 44,87 & 1647 & 41,52 \\
\hline DRUOP6 & 3476 & 15677 & 12604 & 80,39 & 7254 & 47,04 & 999 & 28,75 & 948 & 27,27 \\
\hline POS $\mathrm{CCE}^{7}$ & 2554 & 11520 & 10714 & 93 & 4059 & 35,82 & 930 & 36,40 & 447 & 17,50 \\
\hline PO DCA ${ }^{8}$ & 208 & 938 & 1097 & 116,95 & 465 & 50,40 & 105 & 50,59 & 83 & 40,06 \\
\hline TA OP9 & 170 & 768 & 643 & 83,72 & 213 & 28,22 & 58 & 33,89 & 35 & 20,71 \\
\hline TOTAL & 19213 & 86651 & 79517 & 92,90 & $\begin{array}{l}31 \\
081\end{array}$ & 36,47 & 6430 & 33,47 & 5089 & 26,49 \\
\hline
\end{tabular}

The disparity between this situation and the allocated sums is further amplified by the results that indicate the highest absorption rate for the Regional Operational Program(41,5\%) and the Developing Administrative Capacity Operational Program 
$(40,06 \%)$, while the operational programmes with the lowest absorption rate are Transport OP $(19,8 \%)$ and Economic OP (17,5\%). (See Regulation (EC) no. 1080, 1081, 1083, 1084/2006)

While most new member states focus on Transport OP and Environment OP, in Romania the situation has remained unchanged each year; that is Regional Operational Program has top priority ahead of any operational programme. Given that Transport OP has the highest allocations, but registers the lowest absorption rate $(6,46 \%)$, it can be concluded that the Romanian authorities that manage these fields face a very serious problem. At the end of 2013, the absorption rate was $26,46 \%$, and in September 2014, it was approximate 36\%.(CIAP, 2012; RNSF 2007-2013, 2006)

In order to identify the factors that formed the intention of the beneficiaries to propose projects for financing from structural funds also in the next programming period, we used a regression model, which concluded the following results:

Table 4: Model Summary

\begin{tabular}{|c|c|c|c|c|c|c|c|c|c|}
\hline \multirow[b]{2}{*}{ Model } & \multirow[b]{2}{*}{$\mathrm{R}$} & \multirow[b]{2}{*}{ R Square } & \multirow[b]{2}{*}{$\begin{array}{c}\text { Adjusted R } \\
\text { Square } \\
\end{array}$} & \multirow[b]{2}{*}{$\begin{array}{c}\text { Std. Error } \\
\text { of the } \\
\text { Estimate }\end{array}$} & \multicolumn{5}{|c|}{ Change Statistics } \\
\hline & & & & & $\begin{array}{c}\text { R Square } \\
\text { Change }\end{array}$ & F Change & df1 & df 2 & $\begin{array}{c}\text { F } \\
\text { Cha } \\
\text { nge }\end{array}$ \\
\hline 1 &, $894^{2}$ &, 798 &, 796 &, 197 & ,798 & 300,951 & 2 & 152 &, 000 \\
\hline
\end{tabular}

a. Predictors: (Constant), the role of SF in the role SF has in the economic development process economic development of the country, the degree of of the country, and the variation of the degree of accessibility of SF in Romania accessibility for the absorption process of SF, explains the variation of the intent of Model summary outlines the fact that a fairly significant beneficiaries to apply financing requests for the percentage $(79,8 \%)$ of the variation of the 2014-2020 period as well.

Table 5: ANOVA

\begin{tabular}{|l|r|r|r|r|r|}
\hline Model & Sum of Squares & df & Mean Square & F & Sig. \\
\hline Regression & 23,302 & 2 & 11,651 & 300,951 &, $000^{2}$ \\
Residual & 5,885 & 152 &, 039 & & \\
Total & 29,187 & 154 & & & \\
\hline
\end{tabular}

a. Predictors: (Constant), the role of SF in the economic development of the country, the degree of accessibility of the absorption process in Romania 
b. . Dependent Variable: the intention to submit projects for financing from SF in the future programming period 2014-2020

The ANOVA table signals the existence of a regression model which is significant from a statistical point of view between the three variables: " the role of SF in the economic development of the country", " the degree of accessibility of the absorption process in Romania" and " the intention of beneficiaries to submit projects for financing from SF in the future programming period 2014-2020".
Table no.6

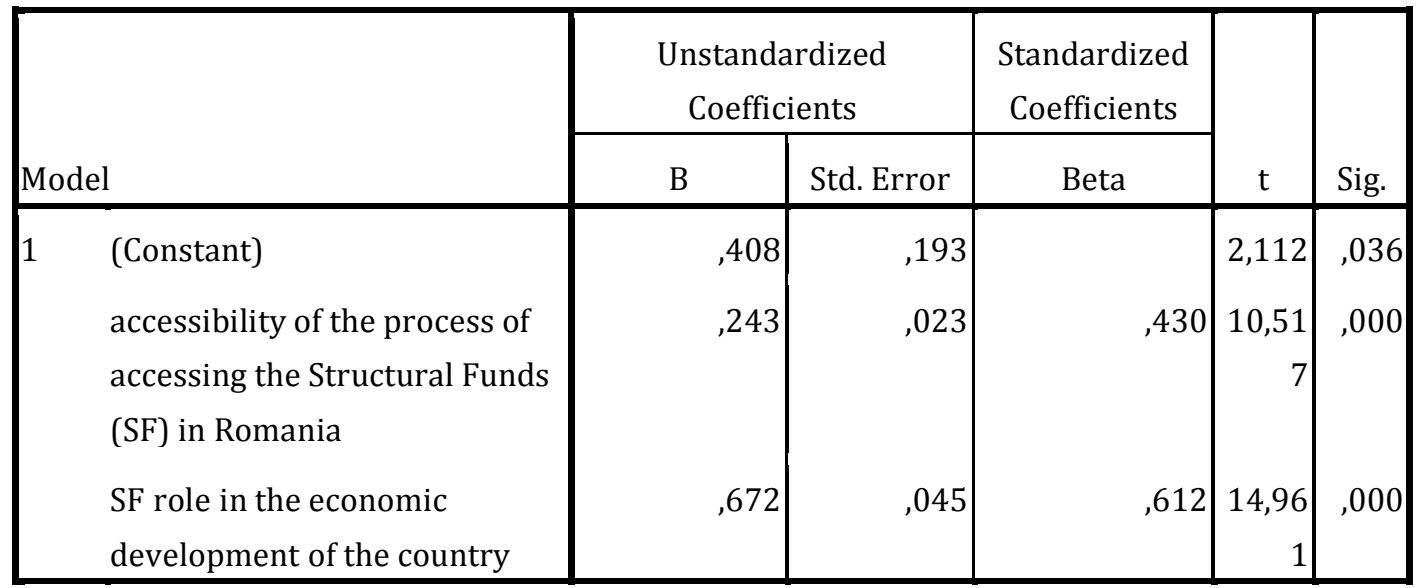

a) Dependent Variable: the intention to submit projects for financing from SF in the future programming period 2014-2020
The importance of structural funds in the process of Romania's economic development, from the perspective of the beneficiaries, is the factor which offers the strongest reasoning for their intent to further submit projects in the future, in the 2014-2020 programming period. The second factor that forms the intention of the beneficiaries to submit projects for financing is the general level of accessibility of the absorption process for structural funds in Romania.(see Theurer M, 2011; Isărescu, M., 2008).

Both the beneficiary organizations as well as those who have not benefited from structural funds consider themselves to be well prepared for the next programming period. The actions undertaken by beneficiary organizations and management structures in this field consist of: the experience accumulated during the current programming period, participation in courses/seminars and conferences on accessing structural funds, and participation in drafting the development strategy of the community/region. On their part, the organizations that have not benefited from structural funds financing have mentioned, as main preparatory action for the 2014-2020 programming period, monitoring specialized websites, followed by participation in courses/seminars and conferences on structural funds, participation in drafting the development strategy of the community, as well as establishing a specialized department for accessing structural funds.

The expectations of the organizations for the following programming period consist of 
proposals for solving the problems that affect their activity. These mainly cover: granting financial aid from the government for preparing/implementing projects, raising administrative capacity, reducing the bureaucracy level, improving the legal framework, simplifying the accession process and the public procurement procedures, improving and modernizing the evaluation system of the financing and reimbursement requests, as well as training and improving in the field of project management/structural funds accessing of the public administration personnel, in general, and of the personnel directly involved in managing non-refundable funds, especially.

The results of qualitative research, which studies the perception of the authorities responsible for the management of structural funds in Romania (Management Authorities and Intermediate Bodies), outline as main factors that lead to extremely big differences between the number of requests filed and those contracted, that of the lack of correlation between some sections of the financing request and the general and/or special conditions of the Applicant's guide, the low quality of the financing requests, poorly skilled personnel both for drafting the project, as well as the management and implementation team.

While beneficiaries refer to specific, wideraging issues, the bodies that manage them focus on technical aspects, strictly linked to how the financing requests are drafted. The main conclusion is that these institutions are strictly oriented on control, check-up and following bureaucratic procedures and less or almost not at all on identifying the real issues of the accessing process or adopting measures to alleviate and/or reduce these difficulties. Practically, they are interested only in respecting standards, not in offering support to beneficiaries in order to draft projects that would reduce the "handicap" of Romania in accessing structural funds.

For the Management Authorities (MA) and the Regional Intermediate Bodies (RIB), the absorption of structural funds is a unanimously accepted issue, but none of these hesitated in making statements regarding the positive situation registered by the operational programme which they represent. The only statement which is fairly realistic is that made by the representatives of the OP Transport, who are dissatisfied with the way the absorption process is evolving in general and the absorption process of the operational programme which they manage, in particular. (See Murch R. 2001, Neagu, C. 2007).

The view of these institutions is that the issue of accessing structural funds is based on the fact that "at the time when the National Strategic Reference Framework was developed, relying on the statistic analysis of the activity sectors, GDP/1000 inhabitants, as well as the existent needs, there was no forecast of any economic crisis."

Considering "a series of documents and guides, aimed at simplifying the work methodology and supporting the beneficiaries", which they drafted, the MA's and RIB's consider that the structural funds accessing process in Romania is fairly approachable, and the factors which any beneficiary/potential beneficiary has to bear in mind in order to achieve a guaranteed success in receiving financing, are: following the provisions of the Applicant's guide, following EU legislation and clearly defining the need/project idea while correctly placing it within the project, the institutional capacity of the bodies which are named for monitoring and checking implemented projects, the public procurement process and the correctness of the project implementation.(see www.businessday.ro, www.gov.ro, www.mfin.ro, www.maeur.ro, www.fonduriue.ro).

According to their perception, the benefits that the structural funds bring to the national economy can be divided into four categories, namely: (1) net state income and supporting projects in the context of the irregularities discovered during project implementation, (2) supporting large scale projects, which could not be financed from other sources, (3) benefits linked to the purpose of allocating structural funds for the Romanian government, which are 
considered an important instrument for developing the economy and (4) the last category, which is defined by an unclear statement of the benefits, as a result of the fact that the respondents have not presented specific aspects, but they have limited themselves to making relative statements such as "they certainly have a contribution to the economic growth of a country".

Enache C. (2015) mentioned that Romania, as an EU member state, supports developing countries to integrate trade into their national development policies, in programs and strategies to reduce poverty by regulations related to technical assistance for the participation of these countries in the negotiation and implementation of DDA results.

The expectations of these institutions regarding the 2014-2020 programming period concern different aspects, such as: affirming the importance of structural funds in the socioeconomical development of the country, reviewing the legislation regarding public procurement and simplifying these procedures, achieving a high absorption rate, focus on project that develop the competitive edge of the regions, as well as partnerships developed within the regions.

An interesting result regarding their expectations points towards an increase in the performance of structural funds management, a situation which is contradictory to their opinions on the aspects that formed the subject of the query: considering that all institutions believe that the performance achieved in managing structural funds in 6 years of implementation is very good, the level of training of the specialists that work in them is very high, and the effort to back the 2014-2020 programming period poses no problems, as a result of the very good training they have received especially for this new experience.

The problems that have led to Romania being the last in the European Union in structural funds absorption are varied and complex, as they concern the following aspects:
$>$ the poor training of the human
resources;

$>$ the faulty functioning of the Management Authorities and Intermediary Bodies: inefficient cooperation with the beneficiaries, defective communication, lack of expediency;

problems with the public procurement procedures: conflicts of interest, shady procedures, procedures that are difficult to follow, restrictive, unclear and unstable selection criteria;

excessive bureaucracy: an excessive number of justification documents for the same subject, the difficulty in drafting the documentation for preparing a project, the focus on the form of the financing dossier and less on the contents, the complexity of the documentation that needs to be sent periodically, the difficulty, complexity and instability of the provisions of the Applicant's Guide;

$>\quad$ financial issues: the lack of resources for preparing and implementing a project, the incapacity to co-finance, the lack of cash-flow, the lack of resources to motivate the personnel, the lack of funds for professional training/development of the personnel, the reimbursement period is too long;

$>$ problems encountered during the documentation drafting/project planning phase: difficulty in obtaining approvals, the influence of the political factor, the deterioration of the relationships with project partners, the difficulty and complexity of the provisions within the Applicant's Guide;

$>\quad$ problems in the evaluation phase of the financing/reimbursement requests: the lack of transparency in this process, the very big length of the evaluation period, unstable and subjective evaluation criteria;

$>\quad$ the freezing of payments for operational
programmes;
$>\quad 2010-2012$-the period of downfall in
accessing structural funds;
$>\quad$ political and institutional instability.

All of the aforementioned issues can be reduced to a common denominator - the "political factor": as a result of an impressive number of governments ( 6 governments in 6 
years) and the continuous conflicts between the state institutions, political instability has been ceaseless, leading to government officials focusing their attention on other matters, different from those aimed at identifying solutions for accelerating the absorption process.

In order to accelerate the increase of the absorption level of structural funds, the Romanian government has taken the following short-term measures:

$>\quad$ more projects, more European funding - an expedient project filing and contracting programme has been launched for all operational programmes, and POSDRU has been launched with a 1,3 billion euro sum which is still not granted;

$>$ over-contracting the operational programmes at priority axes level;

$>$ exemption of the beneficiaries from paying penalties, penalty interests and attachments to the state for overdue fiscal obligations, if the authorities assigned with the management of structural funds have registered delays in payments owed to them;

$>$ the possibility of the MA's to automatically decommit the project savings made by the beneficiaries;

$>\quad$ finalizing, by the end of July, the evaluation of the projects filed in 2010;

$>\quad$ recruiting experts to assist the MA's

in the project evaluation and inspection process;

$>\quad$ increase the pre-financing granted to the Regional Development Agencies from 10\% to $35 \%$;

$>\quad$ filing justification documents only in electronic format for POSDRU;

$>$ making partial payments to beneficiaries who have not submitted the complete reimbursement documentation;

Also, future actions will focus on:

$>\quad$ over-contracting Operational Programmes, from one programme to the other;

revising the legal framework for public procurements, which will contribute to redeeming a clear and concise nature for the public procurement procedures, as well as making the institutions charged with verifying contracts in this field more responsible;

drafting a guide for interpreting Emergency Government Ordinance 66/2011 regarding the prevention, detection and sanction of irregularities in obtaining and using European funds, which will include opinions and points of view of all institutions involved in public procurement;

$>\quad$ the delegation to the banking system of the responsibility to make payments to the beneficiaries, in order to create an efficient a transparent financial route for achieving complementarity of the operational programmes.

Although the measures already adopted, as well as those that will be taken in the near future, are not designed to solve all the problems of the beneficiaries and the management authorities of the structural funds, they represent a first step in offering support and security to potential beneficiaries, with regard to their possibility of accessing structural funds.

Moreover, the results show that the main issue confronting all public institutions - the training of the human resource - has thus far not been tackled at all.

Therefore, the main recommendation in solving the problem of structural funds absorption concerns human resource. More precisely, an objective and fair evaluation process should be considered for the personnel of public institutions, in particular, to identify the training and knowledge level, especially for those civil servants within MA's and IB's, as well as those within departments charged with planning and implementing projects in public institutions. Organizing training and specialization courses/programmes for the personnel in the fields of project management and structural fund absorption is vital for Romania, in order to contribute to the reduction of the number of rejected projects, so that at least in the homestretch the absorption percentage will rise. Such training is the foundation for the good functioning of any 
public institution that wishes to achieve maximum efficiency and to substantially contribute to the development of the community, through non-refundable funds, because "a public administration system, which has sufficient material and financial resources, but professionally and managerially untrained public servants, will not achieve the desired results" (Marinescu, 2003, chapter VIII).

The second measure focuses on opening positions in the field of structural funds accession. The recommendation concerns both the AM's and the IB's, but especially the local public administration. Most organizations of the quantitative study invoke the lack of training and insufficient staff to implement projects, so that an increase in the number of employees, within institutions that are most affected by this deficit, would enhance the chances of attracting structural funds in the respective community.

The third measure which should be applied focuses on revising the legislation, in the sense of simplifying the procedures for accessing structural funds. Furthermore, the law regarding public procurement in Romania has many gaps, which lead to defrauding this process with too great an ease. Last but not least, according to the beneficiaries' opinion, the adoption of a specific law for the evaluation of projects financed through structural funds is an instrument for increasing the efficiency of the evaluation process, through establishing deadlines for evaluating a project.

The fourth recommendation concerns the development of administrative capacity through the development of the strategic capacity of public institutions. Making a correlation between local and regional needs, national and European, and a most realistic identification of Romania's needs for development constitutes the premises for achieving a much higher absorption rate compared to the 2007-2013 programming period, according to the recommendations made by the beneficiaries.

The fifth measure reflects the need to decentralize the accessing process by regionalizing Romania. Another noteworthy aspect is the creation of an on-line system for filing financing applications and reimbursement files.

The main recommendations for improving the structural funds accessing framework, coming from the institutions and bodies charged with managing structural funds in Romania concern the following aspects:

an awareness for all the entities involved concerning the major importance of attracting non-refundable financial resources for the economic development of Romania;

an increase in the performance of the structural funds management;

$>$ simplifying the accessing/implementation process for structural funds by establishing clear and stabile rules;

$>\quad$ focus on projects that are in harmony with the real regional development needs and which develop their competitive edge;

$>$ focus on implementing projects in partnerships between the institutions within the regions.

A particular aspect that has drawn our attention is the financial allocation for $\mathrm{OP}$ Major infrastructure within the future programming period. Although this operational programme has been created as a result of merging OP Environment and OP Transport, the proposals of the Romanian government contain a financial allocation which is $20 \%$ lower compared to the current programming period. Considering the negative experience gathered by the two operational programmes in the 2007-2013 programming period, but also the fact that the sum will be much lower, the main recommendation concerns paying special attention to this programme. Although one of the main issues that address Romania is that of the transportation infrastructure, the sums attracted from the funds designated for this field are the lowest. A much lower financial allocation might help avoid the danger that Romania will neglect this programme, precisely because of the incapacity to manage this programme. Considering that infrastructure projects, both environment and transportation, have medium and long term effects, with a 
completion timeframe of even years, the interest of Romanian authorities is lower, because their completion can even outlast a mayor's term, or that of a county council president, member of parliament etc. Therefore, Romanian politicians prefer to focus on a greater number of projects that can be completed in a short term, with immediate effects, a situation that can be favourable in electoral campaigns, the promising speeches that take place during these events thus remaining only at a "fairytale" level.

\section{Conclusions}

In conclusion, it can be said that Romania has a great responsibility regarding the reduction and then elimination of the essential problems that make structural funds absorption difficult. To start with, a special attention needs to be given to resolving fundamental problems regarding the modernization and development of the system. In this respect, the acceleration of the public administration reform process is essential, by creating a core of competent, specialized and politically independent civil servants, as opposed to the defective system currently operating in Romania, a system which is largely a result of corruption, nepotism and/or political involvement. Obviously, this is a complex and lengthy process which involves creating a partnership between all decision-making entities, and which is almost impossible amidst the permanent conflict between the state institutions. Nevertheless, all decision-making factors must be aware that the current programming period, and especially the 20142020 period, can achieve significant performances only by laying the foundations of an effective management system, by adopting effective measures for simplifying the accessing and management process, as well as by preventing such events that could affect this field.

It can be said that, although concerning contracting, all $\mathrm{C}-\mathrm{EE}$ states have managed to overpass the $70 \%$ threshold, the performance regarding payments made is not the same, registering significant differences with varied percentages ranging from $14 \%$ to $44 \%$, none of the states being able to reach $60 \%$.

\section{Acknowledgement}

This work was co-financed from the European Social Fund through Sectoral Operational Programme Human Resources Development 2007-2013, project number POSDRU/159/1.5/S/142115 „Performance and excellence in doctoral and postdoctoral research in Romanian economics science domain".

\section{Notes} ${ }^{1} \mathrm{C}-\mathrm{EE}$ states $=$ Central and Eastern European
states

\section{References}

1. Bârgăoanu, Alina, (2004), "European financing”, Publishing Comunication.ro, Bucharest.

2. Curteanu, Doru (2005), "Management of public projects", Publishing EfiCon Press, Bucharest.

3. Florescu, Margareta, (2008), "Management of public projects", Publishing Curtea Veche, Bucharest.

4. Ibraim, M., (2007), "Structural instruments - A new chalange for Romania. The flow of post-accession European funds", Contability and Public Finances Magazine, no. 5, p. 23.

5. Marinescu Paul, Managementul instituțiilor publice, cap. VIII, 2003, București, online la http://ebooks.unibuc.ro/StiinteADM/marines cu/cuprins.htm

6. Murch, Richard, (2001), "Project management-best practices for IT professionals, Prentice Hall PTR, USA.

7. Neagu, Cibela, (2007), "Projects Management", Publishing Tritonic, Bucharest. 
8. Inter institutional Committee for the Partnership Agreement (CIAP), Consultative document in order to develop The Partnership Agreement for Romania 2014-2020 - Draft, online la http://www.fonduriue.ro/res/filepicker_users/cd25a597fd62/2012-2020/doc/draft_AP_06.06.2013.pdf, 2013, Bucharest

9. Isărescu, Mugur, European funds in Romania and the economic-financial perspective in 2008, National Bank of Romania' Publishing, 2008, Bucharest

10.KPMG, EU Funds in Central and Eastern Europe - Progress Report 2007-2012, online la http://www.kpmg.com/PL/pl/IssuesAndInsig hts/ArticlesPublications/Documents/2013/E U-Funds-in-Central-and-Eastern-EuropeProgress-report-2007-2012.pdf, 2013

11.Michael, Theurer, Work document regarding the absorption of cohesion and structural funds : lessons for the EU cohesion future, European Parliament - the Commission for regional development, 2011

12.Romania's Government, 2007-2013 Reference National Strategic Framework available online at http://eufinantare.info/Documente/CNSR.pdf, 2006(RNSF 2007-2013, 2006)

13.Enache C.(2015)-"An econometric analysis of Romania's agricultural foreign trade with developing countries", Journal of Eastern Europe Research in Business and Economics, IBIMA Publishing (accepted for publishing)

\section{Legislation}

Regulation (EC) no. 1080/2006 of European Parliament and Council regarding the European Fund for Regional Development Regulation (EC) no. 1081/2006 of European Parliament and Council regarding the European Social Fund Social European and the revocation of Regulantion (EC) no. 1784/1999 Regulation (EC) no. 1083/2006 of Council for the establishment of general provisions regarding the European Fund for Regional
Development, European Social Fund and Cohesion Fund and the revocation of Regulation (EC) no. 1260/1999

Regulation (EC) no. 1084/2006 of Council for the establishment of de instituire Cohesion Fund and the revocation of Regulation (EC) no. 1164/94

GEO no. 66/2011 regarding prevention, observation and amending the detected irregularities within the the use of European funds/national public funds related to these, published in Official Monitor of Romania, I part, no. 461 from 30.06.2011

GEO no. 52/2013 for modification and completion of article no. 13 from GEO no. $64 / 2009$ regarding the financial management of structural funds and their use for convergence objective GD no. $218 / 2012$ for the modification of GDO no. 64/2009 regarding the financial management of structural funds and their use for convergence objective

\section{Internet resources}

www.businessday.ro

www.gov.ro

www.mfin.ro

www.maeur.ro

www.fonduri-ue.ro 